\title{
Attitude of Medical Students about Migrating Abroad: A Cross Sectional Study
}

\author{
Khola Waheed Khan, Sadia Nadeem, Qurat ul Ain, Syeda Fatima Muhammad, Tajalee Zafar, Mehr-un- Nisa
}

\section{ABSTRACT}

Objective: To determine attitude of undergraduate medical student's towards immigration, including preferred choice and reasons for immigration.

Study Design: Cross-Sectional Study.

Place and Duration of Study: The study was carried out on students of Wah Medical College, from January 2019 to June 2019.

Materials and Methods: All students at medical college were included in the sampling frame. A sample of 300 students was taken by random sampling using random number generator. A questionnaire was formulated comprising of two parts. The first part of questionnaire comprised of close ended questions about the age of students their gender, year of education, preferred choice for specialization, desire to migrate or not and preferred destination for migration The second part included reasons for migration and non-migration. The data was analyzed on SPSS version 21.

Results: Almost half of the students (48.3\%) showed intention towards migration. Those who wanted to migrate, United Kingdom was the top choice (27.9\%). Better job opportunities, family reasons and medical facilities were the most common reasons for migration while intention to serve the country, family issues and lack of financial resources were the main reasons to stay in the country.

Conclusion: Half of the students intend to migrate to other countries and favorite destination for work is United Kingdom.

Key Words: Education, Internal Medicine, Migration, Medical Graduates, Specialization.

How to cite this: Khan KW, Nadeem S, Ain Q, Muhammad SF, Zafar T, Nisa M. Attitude of Medical Students about Migrating Abroad: A Cross Sectional Study. Life and Science. 2021; 2(2): 63-65. doi: http://doi.org/10.37185/LnS.1.1.135

This is an Open Access article distributed under the terms of the Creative Commons Attribution License (http://creativecommons.org/licenses/by/4.0), which permits unrestricted use, distribution, and reproduction in any medium, provided the original work is properly cited.

\section{Introduction}

The phenomenon of health professional migration has been known and documented several decades back. Reasons are broadly demographic and epidemiological changes worldwide. ${ }^{1}$ This trend is more prevalent in Asian and African countries as these countries provides least facilities to their doctors and paramedical staff. ${ }^{2}$ These doctors when come in the workforce face the harsh realities of the profession. The amplified workload, lack of support from the government, insecure and poorly paid jobs

Department of Community Medicine

Wah Medical College, Wah Cantt

Correspondence:

Dr. Khola Waheed Khan

Assistant Professor, Community Medicine

Wah Medical College, Wah Cantt

E-mail:drkholakhan_12@yahoo.com

Funding Source: NIL; Conflict of Interest: NIL

Received: Aug 06, 2019; Revised: Dec 30, 2020

Accepted: Feb 12, 2021 compel them to migrate to developed world. This is commonly known as the 'brain drain'.

This migration of doctors as well as supporting staff is the most challenging aspects of globalization that has led to policy changes at the technical and political level. ${ }^{4}$ Most of the countries that are generating doctors are the countries that have huge population and are actually in need of them. These are future leaders that can bring about reforms in academics and research but because of migration trends, there is intellectual, socioeconomic and demographic loses. ${ }^{5}$

Migration and reasons behind migration from developing countries has been addressed in literature but very little is known about Pakistan. A survey conducted at Wah Cantt ${ }^{6}$ showed that international careers were anticipated by $27.2 \%$ of participants with main reasons for immigration were high salary, higher educational opportunities, good working conditions and structured career path. ${ }^{6}$ 
Another study carried at Dow Medical College and Civil hospital Karachi showed that $54 \%$ of the doctors wish to go abroad. Major factors for immigration were better quality of post-graduation training (48.2\%) and economic prospects (35.2\%). ${ }^{7}$

These researches gave a variable view of physician's perception therefore, objective of this study was to determine the attitude of undergraduate medical student's towards immigration, including their preferred destination and reasons

\section{Materials and Methods}

A cross sectional study was carried out on the medical students Jan-June 2019 (6 months). Sample size was calculated three hundred (300) by World Health Organization (WHO) sample size calculator ( $p$ value of 0.27$){ }^{6}$ All students were included in the sampling frame except the students on the foreign seats (students who are not Pakistani nationals) and selected by random number generator. A questionnaire was formulated after extensive literature search. It comprised of two parts. The first part comprised of close ended questions about age, gender, year of education, parent's education, preferred choice for specialization, intention to give post graduate exam, desire to immigrate or not and preferred destination for immigration. The second part was an open-ended questionnaire regarding reasons for immigration and non-immigration. The study was approved by the Institutional Review Board. Informed consent was taken by the participants. The quantitative data was entered and analyzed by SPSS version 21 .

\section{Results}

The mean age was $21.47 \pm 1.97$. There were $137(44.9 \%)$ males. Among the participants, 46(15.1\%) had fathers' and $18(5.9 \%)$ had mothers' with medical education. The number of participants who intend to opt for different specialties were 105 (35\%) in surgery, $90(30 \%)$ in medicine, $50(16.6 \%)$ in Obstetrics/Gynecology and 40 (13.3\%) in Pediatrics. Maximum number of students. $85(27.9 \%)$ want to immigrate to UK. The students with the intention to prepare for postgraduate examination were255(83.6\%) including FCPS 182(59.7\%), PLAB 49(16.1\%), USMLE $38(12.5 \%)$ and $36(11.8 \%)$ other exams. Students without intention to immigrate were $155(51.6 \%)$ while $145(48.3 \%)$ were willing to immigrate. (Figure 1).

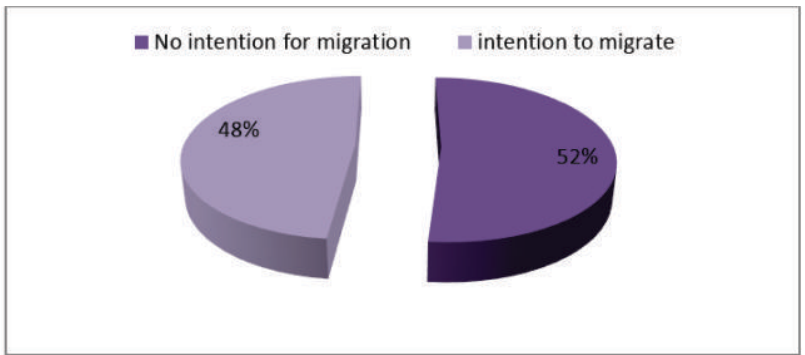

Fig 1: Intention to migrate

Table 1: Reasons for Immigration and Non Immigration

\begin{tabular}{|c|c|c|c|}
\hline $\begin{array}{l}\text { Reasons for } \\
\text { immigration }\end{array}$ & $\begin{array}{l}\text { Percentage } \\
\text { of } \\
\text { students }\end{array}$ & $\begin{array}{l}\text { Reasons for } \\
\text { non- } \\
\text { immigration }\end{array}$ & $\begin{array}{l}\text { Percentage } \\
\text { of } \\
\text { students }\end{array}$ \\
\hline $\begin{array}{l}\text { Better job } \\
\text { opportunities }\end{array}$ & 89 & $\begin{array}{l}\text { Service to } \\
\text { Country }\end{array}$ & 54 \\
\hline $\begin{array}{l}\text { Better facilities } \\
\text { and health } \\
\text { care system }\end{array}$ & 48 & $\begin{array}{l}\text { Family and } \\
\text { related } \\
\text { issues }\end{array}$ & 47 \\
\hline $\begin{array}{l}\text { Medical } \\
\text { education } \\
\text { opportunities }\end{array}$ & 34 & Others & 7 \\
\hline $\begin{array}{l}\text { Economic } \\
\text { reasons }\end{array}$ & 21 & $\begin{array}{l}\text { Lack of } \\
\text { funds }\end{array}$ & 4 \\
\hline $\begin{array}{l}\text { Family and } \\
\text { related issues }\end{array}$ & 11 & Visa Issues & 3 \\
\hline $\begin{array}{l}\text { Appropriate } \\
\text { working hours }\end{array}$ & 6 & & \\
\hline Other reasons & 4 & & \\
\hline
\end{tabular}

\section{Discussion}

This study showed that $52 \%$ students have no intention to migrate which is comparatively less than the results of studies carried out by Nazish Imran et al and Gouda P et al. ${ }^{8,9}$ This trend of non -migration is may be due to the fact that, we have a higher proportion of females (55\%) who cannot think of leaving the country because of our sociocultural dynamics. ${ }^{10}$ The students themselves quote that they want to stay in the country to serve it and there are some family issues which bound them to stay. These results were consistent with other studies carried out in Pakistan ${ }^{7,11}$ which proves that recent stability in the country, better stipend and reduce terrorism have encourage our young doctors to stay and serve in the country.

The students who want to migrate to other countries intend to do so mainly because of better job opportunities, family reasons, medical facilities etc. A research conducted in Karachi and many other international researches also supports these 
observations respectively. ${ }^{5,8,12,13,14,15,16}$ One of the studies stated that major reasons for migrating to the developed world are the new immigration policies and shortage of health workforce. ${ }^{17}$

Surgery was the most preferred choice for specialization of $35 \%$ of students. The result is similar to the study carried out by Mandeville KL et al. ${ }^{18}$ However some national and international studies have shown that most students want to do specialization in relatively new field of internal medicine. ${ }^{7,6,19}$ The interest in the latest fields of medicine is encouraging, showing that our younger generation is trying to keep pace with the developed world.

In our research, most of the students 91(29.8)\% wanted to migrate to UK. This result is consistent with various studies conducted in Pakistan where preferred choice for immigration is UK and USA. ${ }^{6,7,10,11}$ However a research conducted in Sri Lanka and Uganda the participants want to migrate to Australia and America. ${ }^{12,20}$

\section{Conclusion}

Half of the students intend to migrate to other countries and their favorite destination for work is United Kingdom.

\section{Limitations}

The study could have contributed more to the subject but due to restricted time and number of students the scope of the study is limited. A qualitative part of the study could have generated better themes and sub theme for the objectives.

\section{Acknowledgment}

Thanks to Allah almighty for giving us wisdom to do this work, apart from it we would like to thank our parents and family for their encouragement and finally the students for their support in collection of the data.

\section{REFERENCES}

1. Sucio SM, Popescu CA, Ciumageanu MD, Buzoianu AD. Physician migration at its roots: a study on the emigration preferences and plans among medical students in Romania. Human Resources of Health. 2017; 15: 6.

2. Li W, Sun H. Migration intention of Asian and African medical students educated in china: a Cross sectional study. Human Resources of Health. 2019; 17: 88.

3. Shakil SS. Stemming the Medical Brain Drain: A Personal Perspective on a Global Problem.Einstein J. Biol.Med. 2016;
31:11-6.

4. Cometto G, Tulenko K, Muula AS, Krech R. Health Workforce Brain Drain: From Denouncing the Challenge to Solving the Problem. PLoS Med. 2013; 10: e1001514.

5. Kopetsch T. The migration of doctors to and from Germany. J Public Health. 2009; 17: 33-9.

6. Sohail I, Habib M. Brain Drain: Doctors' career intentions and associated factors, a questionnaire survey in Pakistan. J Post grad Med Inst. 2016; 30; 189-93.

7. Hossain N, Shah N, Shah T, Lateef SB. Physicians' migration: Perception of Pakistani medical students. J Coll Physicians Surg Pak. 2016; 26: 696-701.

8. Imran N, Azeem Z, Haider II, Bhatti MR, Brain Drain. A Harsh Reality. International migration of Pakistani medical graduates. J Post grad Med Inst. 2012; 26: 67-72.

9. Gouda P, Kitt K, Evans DS, Goggin D, McGrath D, Last J, et al. Ireland's medical brain drain: migration intentions of Irish medical students. Hum Resour Health. 2015; 12; 11.

10. Vanasse A, Scott S, Courteau j, Orzanco MG. Canadian family physicians' intentions to migrate. Can Fam Physician. 2009; 55:396-7.

11. Imran N, Azeem Z, Haider II, Amjad N, Bhatti MR. Brain Drain: Post graduation migration intension and the influencing factors among medical graduates from Lahore, Pakistan. BMC Research Notes. 2011; 4: 417.

12. Silva APD, Liyanage IK, Silva STGRD, Jayawardana MB, Liyanage CK, Kaunathilake IM. Migration of Sri Lankan medical specialists. Human Resources for Health. 2013; 11: 21.

13. George G, Gow J, Bachoo S. Understanding the factors influencing health worker employment decisions in South Africa. Hum Resour Health. 2013; 23: 15.

14. Lofters A, Slater M, Fumakia N, Thulien N. "Brian drain" and "Brain waste": experiences of international management medical graduates in Ontario. Risk management and healthcare policy. 2014; 7: 81-9.

15. Lofters A, Slater M, Thulien N. The "Brain Drain": factors influencing Physician's migration to Canada. Health 2013; 5:125-37.

16. Tahir MN, Kauser R, Tahir AM. Brain Drain of doctors; Causes and consequences in Pakistan. International Scholarly and Scientific Research and Innovation 2011; 5: 302-8.

17. Humphires $N$, Tyrrell E, McAleese $S$, Bidwell $P$, Thomas $S$, Normand C, et al. A cycle of brain gain, waste and drain- a qualitative sturdy of non- EU migrant doctors in Ireland. Human Resources for Health. 2013; 11: 63.

18. Mandeville KL, Bartley T, Mipando M. Future career plans of Malawain medical students: a cross-sectional survey. Hum Resour Health. 2012; 10: 1-8.

19. Assefa T, Haile Mariam D, Mekonnen W, Derbew M. Medical students' career choices, preferences for placement, and attitudes towards the role of medical instruction in Ethiopia. BMC Med Educ. 2017; 17: 96.

20. Kizito S, Mukunya D, Nakitende J, Nambasa S, Nampogo A, Kalyesubula R, et al. Career intention of final year medical students in Uganda after graduating: the burden of brain drain. BMC Med Educ. 2015; 15: 122. 